\title{
Primary osseous tumors of the pediatric spinal column: review of pathology and surgical decision making
}

\author{
*Vijay M. Ravindra, MD, MSPH, ${ }^{1}$ llyas M. Eli, MD, ${ }^{1}$ Meic H. Schmidt, MD, MBA, ${ }^{1}$ and \\ Douglas L. Brockmeyer, MD1,2
}

${ }^{1}$ Department of Neurosurgery, Clinical Neurosciences Center and Huntsman Cancer Institute, University of Utah; and 2Division of Pediatric Neurosurgery, Primary Children's Hospital, Salt Lake City, Utah

\begin{abstract}
Spinal column tumors are rare in children and young adults, accounting for only $1 \%$ of all spine and spinal cord tumors combined. They often present diagnostic and therapeutic challenges. In this article, the authors review the current management of primary osseous tumors of the pediatric spinal column and highlight diagnosis, management, and surgical decision making.
\end{abstract}

http://thejns.org/doi/abs/10.3171/2016.5.FOCUS16155

KEY WORDS osteoid osteoma; osteoblastoma; osteosarcoma; aneurysmal bone cyst; osteochondroma; eosinophilic granuloma; giant cell tumor

$\mathrm{T}$ UMORS of the spinal canal and vertebral column are classified based on their anatomical location and origin. When considered as a whole, intramedullary, intradural extramedullary, and extradural spinal tumors account for $5 \%-10 \%$ of all pediatric central nervous system tumors. ${ }^{85,101,103}$ Pediatric brain tumors are 6 times more common than pediatric spinal tumors. Among spinal tumors, extradural primary or metastatic tumors account for approximately $50 \%$ of cases, followed by intradural intramedullary tumors $(40 \%)$ and intradural extramedullary tumors $(10 \%){ }^{85,101,103}$ Primary osseous spinal column tumors are rare in children and young adults, accounting for only $1 \%$ of all spine and spinal cord tumors combined. ${ }^{45}$ These lesions can be benign or malignant and often present diagnostic and therapeutic challenges. In this article, we review the strategies currently used for the management of primary osseous pediatric tumors of the spinal column, including benign and malignant lesions, and highlight clinical diagnosis, imaging, and surgical decision making through the use of illustrative case examples.

\section{Clinical Symptoms}

Tumors of the spinal column can present with neurological dysfunction or osseous destruction. In either scenario, the result can be pain, neurological deficit, or rapidly progressive spinal deformity. ${ }^{33,45,81}$ Pediatric patients often present with axial or radicular symptoms, most commonly pain. The timing of symptoms can vary based on pathology. Acute onset can indicate vertebral collapse and potential epidural spinal cord compression, whereas chronic symptoms can be present in the setting of slow-growing tumors. In either scenario, persistent nocturnal back pain, localized pain, and pain unrelated to activity can all be hallmarks of spinal column pathology and should prompt immediate evaluation. ${ }^{33,81}$ Additionally, back pain in a patient with known malignancy should cause concern and prompt evaluation for metastatic disease. ${ }^{6}$

The presentation of spinal column pathology in children depends on the age of the patient and location of the lesion. Tumors causing extrinsic compression of the neural elements in the cervical and thoracic spine can cause upper motor neuron signs or myelopathy, including weakness, hypertonia, hyperreflexia, Babinski sign, and sensory deficits. Tumors causing compression or invasion in the lumbar and sacral regions can present with lower motor neuron signs including hypotonia, hyporeflexia, and bowel or bladder dysfunction (constipation, retention, or incontinence). ${ }^{45}$ Toddlers and infants can have subtler presentations, with irritability, regression of motor milestones, refusal to bear weight, and poor developmental progression. ${ }^{33}$

In the setting of spinal malignancy, nearly $95 \%$ of pa-

ABBREVIATIONS CT = computed tomography; MRI = magnetic resonance imaging; NSAID = nonsteroidal antiinflammatory drug; RANKL = receptor activator of the nuclear factor-kappa B ligand.

SUBMITTED April 1, 2016. ACCEPTED May 26, 2016.

INCLUDE WHEN CITING DOI: 10.3171/2016.5.FOCUS16155.

* Drs. Ravindra and Eli contributed equally to this work. 
TABLE 1. Age ranges and presentation of primary osseous tumors in the pediatric spinal column*

\begin{tabular}{cll}
\hline Age Range (yrs) & \multicolumn{1}{c}{ Benign Diagnoses } & Malignant Diagnoses \\
\hline $0-5$ yrs & Eosinophilic granuloma & \\
\hline $5-10$ yrs & Aneurysmal bone cyst & Osteosarcoma \\
& Eosinophilic granuloma & Ewing sarcoma \\
& Osteoblastoma & \\
& Osteoid osteoma & \\
\hline $10-20$ yrs & Aneurysmal bone cyst & Osteosarcoma \\
& Osteochondroma & Ewing sarcoma \\
& Osteoid osteoma & \\
\hline
\end{tabular}

* Adapted from Dormans \& Moroz, 2007. Promotional and commercial use of the material in print, digital, or mobile device format is prohibited without permission from the publisher Wolters Kluwer Health. Please contact health permissions@wolterskluwer.com for further information.

tients can present with nonspecific back pain, which can complicate the diagnostic picture. ${ }^{38,56}$ Some malignancies-Ewing sarcoma and lymphoma in particular-can present with a myriad of constitutional symptoms (for example, fever, night sweats) that can also mislead toward a diagnosis of infection rather than malignancy. ${ }^{94}$ More than $50 \%$ of pediatric patients with malignant tumors of the spinal column present with neurological symptoms; $; 5$ however, this is less common than the presentation of adults with neurological dysfunction in the same context.

Spinal deformity, including kyphosis, scoliosis, and lordosis, can be present in up to $25 \%$ of children with spinal tumors, but such deformities are rarely the only presenting signs of a spinal tumor. ${ }^{70,102}$ The severity of the deformity relates to the extent of osseous erosion and destruction and neurological deficit; however, a small tumor can cause significant spinal deformity. ${ }^{33,86}$ Inspection of the spine with palpation is essential, as painful scoliosis can indicate the presence of underlying pathology; ${ }^{52}$ in these cases, the tumor is typically located in the concavity of the curve, and the deformity can be secondary to vertebral collapse or a muscular reaction to pain. Additional consideration should be given to spinal deformity after treatment because multilevel laminectomy and radiation therapy have been shown to increase the risk for spinal deformity. ${ }^{27,52}$

A patient's age at presentation can also provide an indication of the potential pathology as certain lesions are more likely to appear at different ages (Table 1). Additionally, the location of the lesion along the spinal column and its topographic location on the vertebra itself can provide information regarding diagnosis (Figs. 1 and 2). In addition to the warning signs mentioned above, additional patterns of presentation (for example, incidence, location) can be clues to a diagnosis. Specific details of various lesions along with their imaging and treatment specifics are presented in further detail below (Table 2).

\section{Primary Osseous Tumors Osteoid Osteoma and Osteoblastoma}

Osteoid osteoma and osteoblastoma are generally benign osseous tumors and account for almost $3 \%$ of all primary bone tumors. ${ }^{39,51}$ Osteoblastomas are larger than 2 $\mathrm{cm}$, more vascular, and more typically involve the vertebral body ${ }^{70}$ lesions smaller than $1 \mathrm{~cm}$ are osteoid osteomas. Lesions between 1 and $2 \mathrm{~cm}$ cannot be entirely differentiated

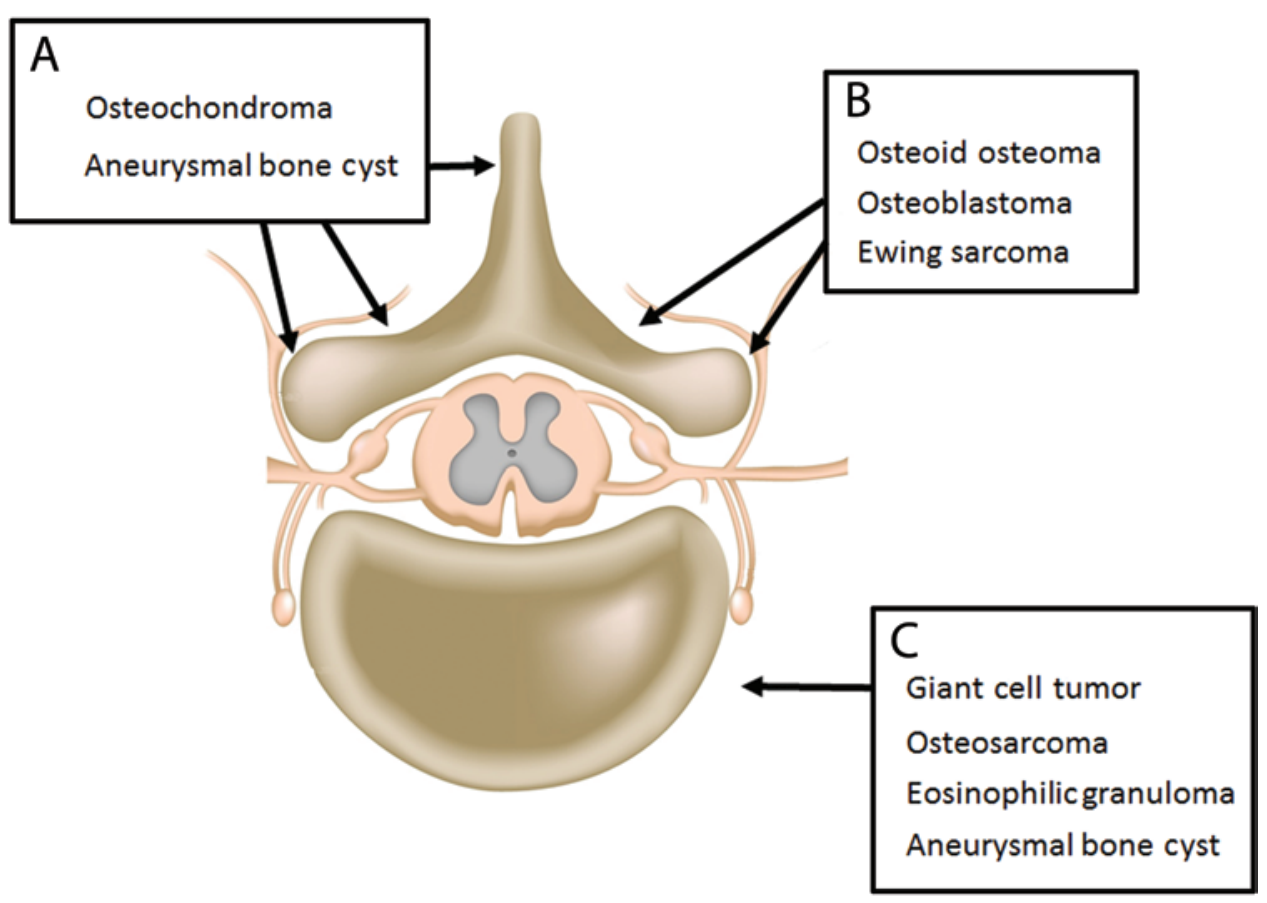

FIG. 1. Most common topographical locations for the occurrence of each of the possible primary osseous lesions in the pediatric spinal column. A: Lesions that occur along the facet joint, laminar arch, and spinous process. B: Lesions that can occur at the facet joint or pedicle or along the laminar arches or pars interarticularis. C: Lesions that occur along the vertebral body. Copyright Fotosearch.com. http://www.fotosearch.com. 


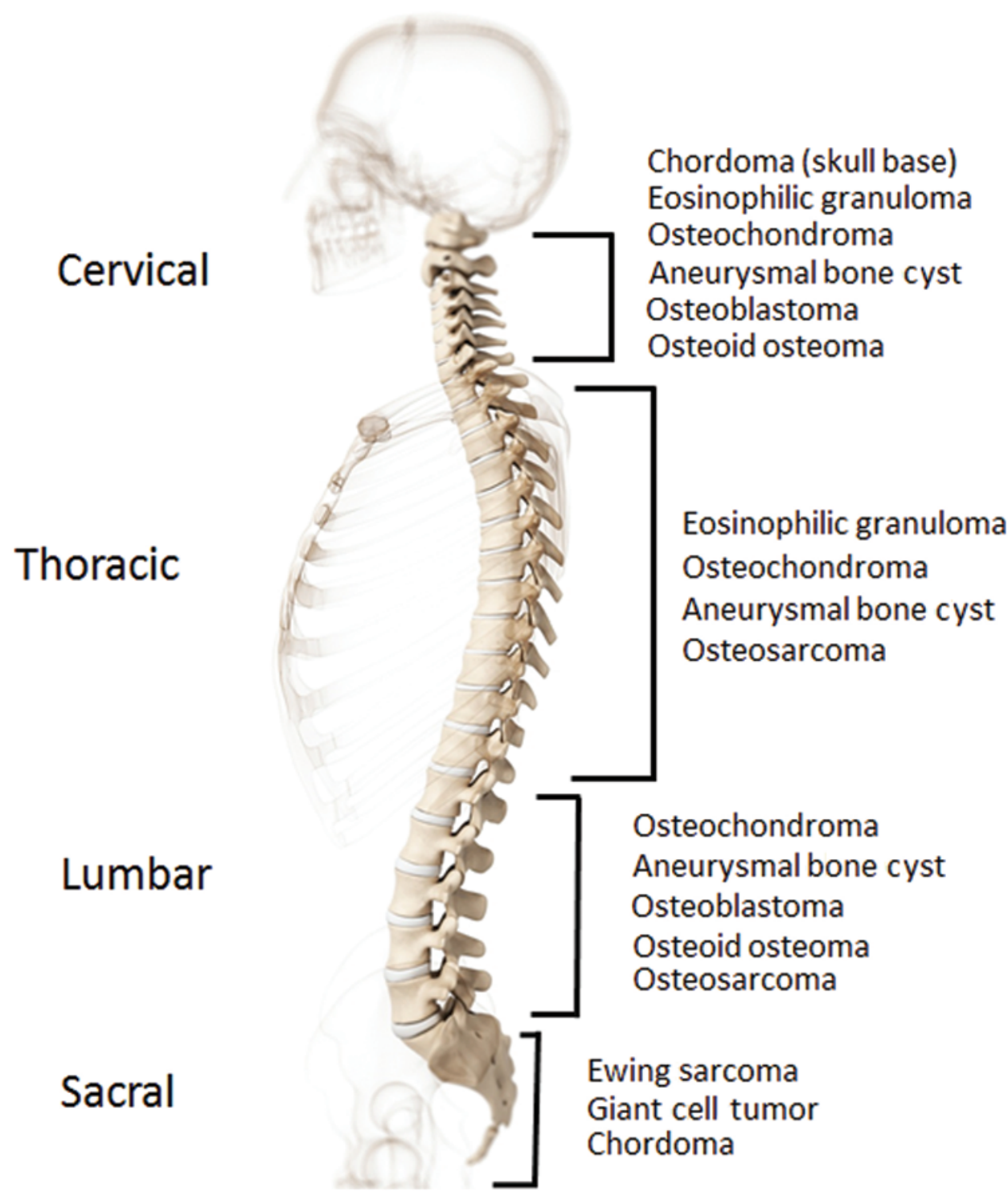

FIG. 2. Distribution of the most common locations for primary osseous lesions in the pediatric spinal column. Copyright Fotosearch.com. http://www.fotosearch.com.

based on size alone. Osteoblastoma accounts for less than $1 \%$ of all benign vertebral column tumors, whereas osteoid osteoma accounts for $9 \%$ of all benign vertebral column tumors. ${ }^{41}$ Almost $25 \%$ of all osteoid osteomas and $40 \%$ of all osteoblastomas are located in the spine. ${ }^{1,4,8,18,23,48,55,68}$ Both of these lesion types are more common in the lumbar spine than in the cervical spine and can occasionally occur in the thoracic spine; ${ }^{86}$ a majority are found in the posterior elements (Table 3). Osteoid osteoma most commonly occurs in the 2nd decade of life, and males are more commonly affected than females. ${ }^{80}$ Osteoid osteomas are benign, latent lesions, whereas osteoblastomas are benign but locally aggressive. ${ }^{27}$ In fact, osteoid osteomas can "burn out" over a period of time..$^{27}$ Although osteoblastomas are historically benign lesions, there have been reports of malignant transformation to osteosarcoma. ${ }^{4}$

The pathological findings of osteoid osteoma and osteoblastoma are similar; both demonstrate bone formation by osteoblasts producing osteoid and woven bone. The primary differentiation is based on size, as mentioned above. However, these lesions can also differ in gross intraoperative appearance and behavior. Osteoblastomas are friable, hemorrhagic mass lesions and are well circumscribed from the surrounding bone, ${ }^{51,52}$ whereas osteoid osteomas have a sclerotic appearance and appear hyperdense and expansile on computed tomography (CT), without evidence of bony destruction (Fig. 3). Osteoblastomas commonly have a "ground-glass" appearance on CT and usually present in the cancellous bone of the lamina or pedicles of the cervical and lumbar spine (Fig. 4) ${ }^{45}$ Osteoid osteomas grossly appear firm and sclerotic and can have a granulomatous component. ${ }^{51,52}$

Osteoblastoma and osteoid osteoma also share many clinical presentation findings, but osteoblastomas are more likely to present with neurological deficits because of their larger size ${ }^{80}$ and because they are not typically responsive 


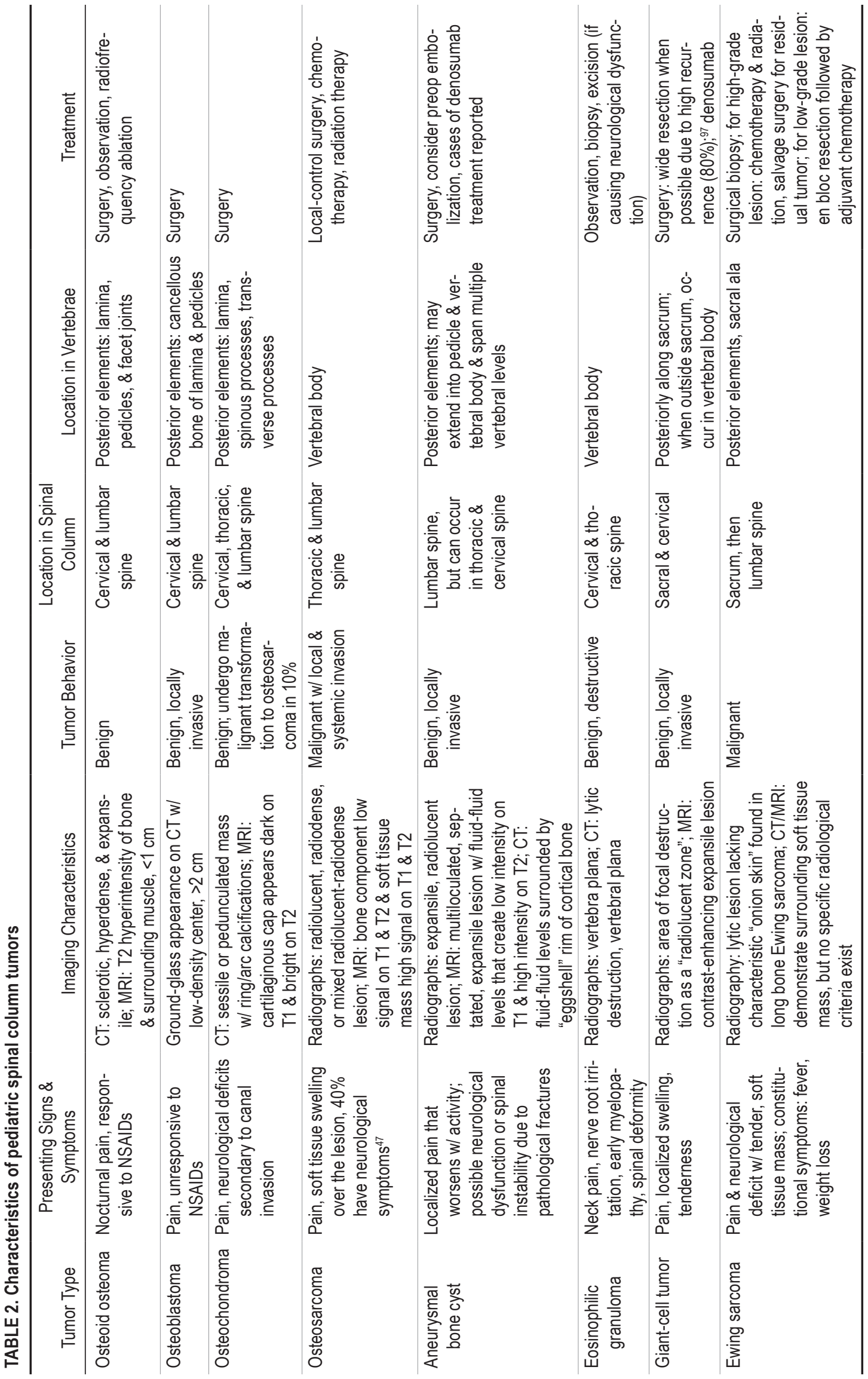


TABLE 3. Primary osseous spinal column tumor locations within the vertebra

\begin{tabular}{|c|c|c|}
\hline Location in Vertebra & Malignant & Benign \\
\hline Anterior elements & Osteosarcoma & $\begin{array}{l}\text { Eosinophilic granuloma } \\
\text { Giant cell tumor } \\
\text { Hemangioma } \\
\text { Osteoblastoma }\end{array}$ \\
\hline Posterior elements & Ewing sarcoma & $\begin{array}{l}\text { Aneurysmal bone cyst } \\
\text { Osteoblastoma } \\
\text { Osteoid osteoma } \\
\text { Osteochondroma }\end{array}$ \\
\hline
\end{tabular}

to nonsteroidal antiinflammatory drugs (NSAIDs). Osteoid osteoma most commonly presents with localized pain over the lesion, but radicular pain can be present in the setting of nerve root compression or irritation. ${ }^{51}$ The characteristic pain is severe but intermittent and will worsen with activity and is motion related; the hallmark finding is nocturnal pain that is relieved with the use of aspirin. ${ }^{51}$ Moreover, NSAIDs can be used to control symptoms of osteoid osteomas that are difficult to access surgically. ${ }^{27}$

Magnetic resonance imaging (MRI) of an osteoid osteoma often demonstrates T2 signal hyperintensity of the bone as well as the surrounding muscle. In either osteoid osteoma or osteoblastoma, the onset of clinical symptoms can precede the formation and identification of findings on plain radiography or CT. In this scenario, if there is high clinical suspicion, MRI and nuclear medicine radioisotope studies may be more sensitive in detecting smaller lesions; ${ }^{45}$ specifically, single-photon emission computed tomography (SPECT) can be helpful in diagnosing osteoid osteomas. An additional finding with both lesions is a high incidence of spinal deformity; Saifuddin et al ${ }^{86}$ reported that $293(63 \%)$ of 465 children with either osteoid osteoma or osteoblastoma had scoliosis.

Management of these lesions can vary based on location, severity of symptoms, and associated neurological symptoms. For children with suspected osteoid osteoma and minimal symptoms that are easily controlled, observation may be appropriate as some of these lesions can spontaneously involute. ${ }^{45}$ Patients experiencing persistent pain or neurological symptoms may be candidates for excision, with gross-total resection as the primary goal. In cases in which gross-total resection is achieved, pain resolution and tumor control are excellent. In addition, there can be significant improvement in spinal deformity after resection; Ozaki et al. ${ }^{77}$ reported improvement in 16 (94\%) of 17 patients after the removal of either osteoid osteoma or osteoblastoma.

There is a $10 \%$ risk of local recurrence after resection of either lesion..$^{36,39,80}$ Excision of osteoblastomas should include extended intralesional curettage with resection of the entire nidus as the goal. ${ }^{27}$ Fusion adjuncts and stabilization may be indicated for lesions in which resection will result in spinal instability. ${ }^{27}$

Because of the small size of these lesions, preoperative and intraoperative localization can be a challenge. Similarly, in the case of osteoid osteomas, the sclerotic appearance of the lesion in comparison with adjacent bone can make localization difficult. Although techniques such as CT-guided dye injection or intraoperative radioisotope scanning have been described, $, 14,59$ they are not necessary with careful preoperative planning. For recurrent osteoid osteoma or osteoblastoma, the treatment options are resection or radiation therapy. For osteoid osteomas, the risk of radiation-induced malignancy is less than $1 \%,{ }^{67}$ but reop-
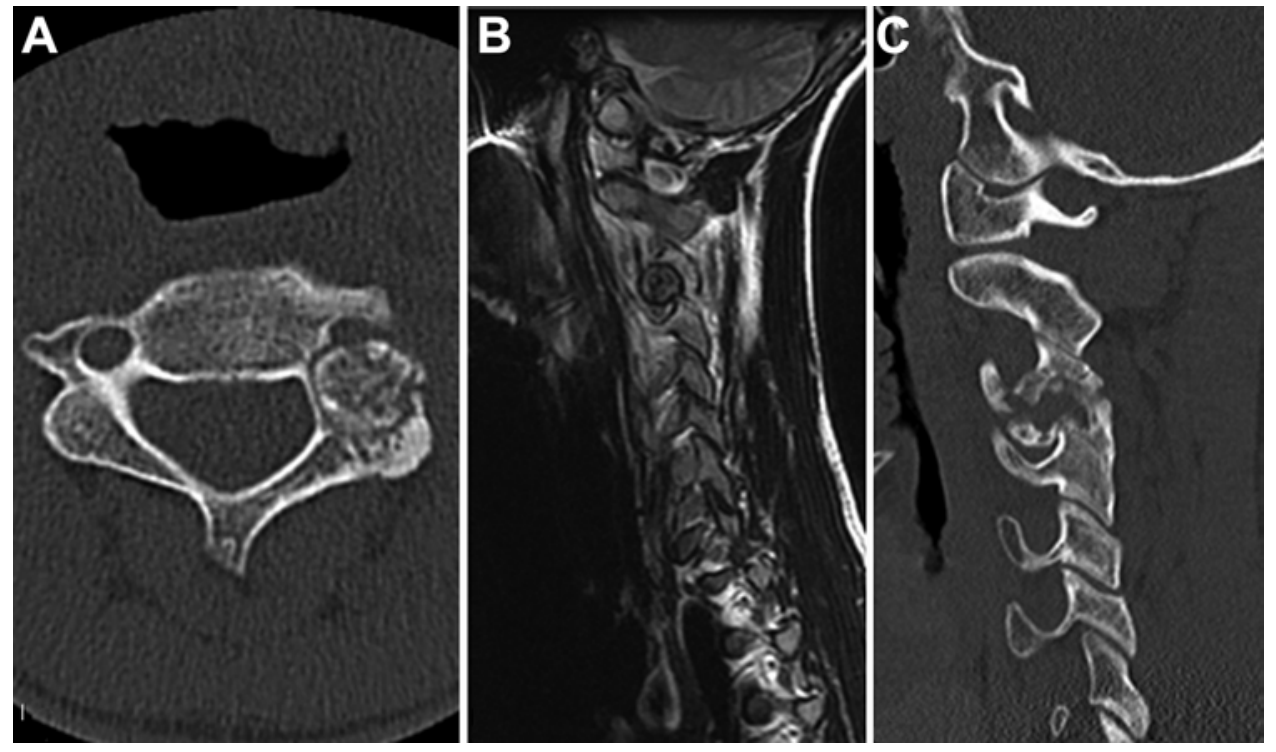

FIG. 3. A 16-year-old boy presented with severe neck pain and neck spasms. His neck pain was initially worse at night and responsive to nonsteroidal antiinflammatory drugs (NSAIDs). A: Axial CT showed a 1-cm sclerotic mass centered in the left pars and pedicle of C-3 associated with narrowing of the C-3 vertebral artery canal. B: On sagittal T2-weighted MRI, the lesion was hypointense. C: Sagittal CT showed resection of the lesion, which was identified as an osteoid osteoma, via a left C-3 hemilaminectomy. Repeat imaging 10 months after surgery demonstrated no evidence of spinal instability or malalignment, and the patient has been clinically stable for 3 years. 

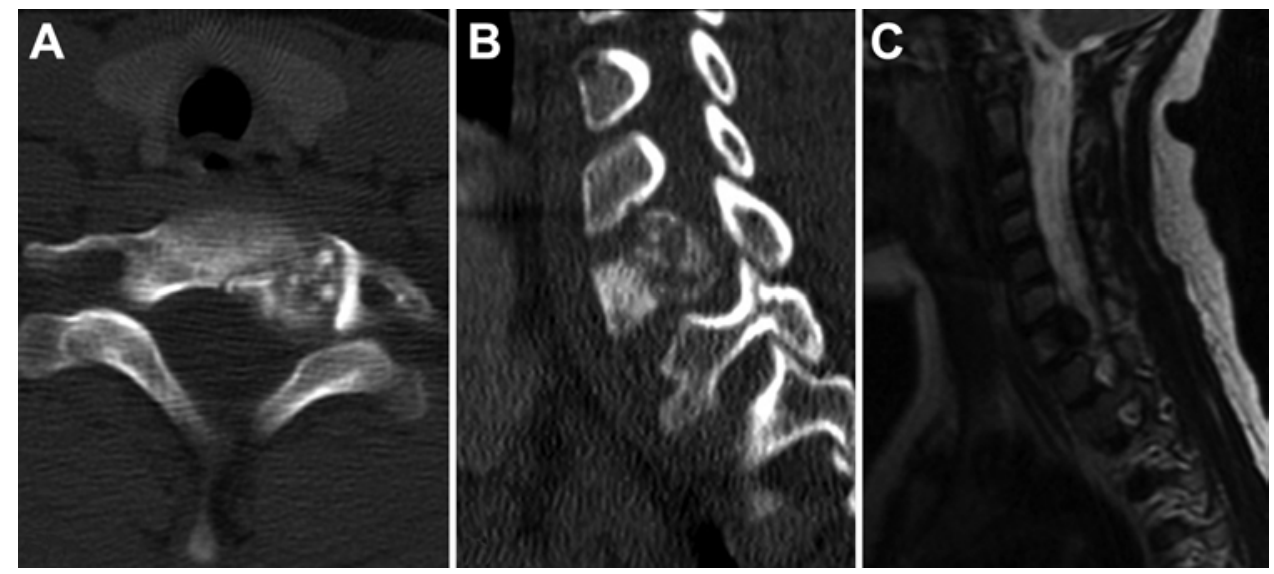

FIG. 4. A 7-year-old girl presented with progressive neck pain that was unresponsive to NSAIDs. Axial (A) and sagittal (B) CT demonstrated a destructive bone lesion measuring $2.2 \mathrm{~cm}$ in the left C-7 pedicle and vertebral body. Pathological analysis of the biopsy specimen indicated a diagnosis of osteoblastoma. Repeat MRI (C) 4 years later showed no recurrence, and the patient continues to do well 10 years after surgery.

eration is recommended for recurrent or residual lesions if the location is amenable. ${ }^{4,36,39,51,73}$ Additional treatment options can include radiofrequency ablation with or without CT guidance, which has shown good results in deactivating osteoid osteoma. ${ }^{43,69}$ Vanderschueren et al. ${ }^{98}$ reported on 24 patients who underwent radiofrequency ablation for osteoid osteomas, 19 of whom were successfully treated. The authors concluded that radiofrequency ablation can be used in osteoid osteoma without nerve root compression and can also improve scoliosis associated with spinal osteoid osteoma (4 [57\%] of 7 patients).

\section{Osteochondroma}

Osteochondromas, also known as osteocartilaginous exostosis, represent $30 \%-40 \%$ of benign osseous tumors and $4 \%$ of solitary spinal column tumors ${ }^{45}$ making them the most common bone tumor in children and adolescents. Patients with osteochondromas present between 10 and 20 years of age. The tumor can occur in the setting of hereditary osteochondromatosis, which is an autosomal dominant syndrome, or as a solitary sporadic lesion, which is the more common presentation. Males are more likely than females to have osteochondromas (2.5:1). . $^{3,108}$ Approximately $1 \%-7 \%$ of all osteochondromas occur in the spine. They most commonly affect the cervical spine (Fig. 2), which is involved in $>50 \%$ of reported cases, and are often located along the laminar arches, transverse processes, and spinous processes (Figs. 1 and 5)., 3,90,108 Osteochondromas can involve multiple spinal levels and extend from the lamina into the spinal canal and neural foramen, leading to neurological dysfunction and spinal deformity in addition to back pain., ${ }^{3,108}$

Because osteochondromas are primarily cartilaginous, plain radiographs can be inadequate in assessing them; $\mathrm{CT}$ or MRI may be necessary for the diagnosis. Computed tomography can demonstrate a sessile or pedunculated mass with ring and/or arc calcifications; MRI demonstrates the lesion with a distinct cartilaginous cap that can appear dark on T1- and bright on T2-weighted imaging. The natural history of osteochondroma is slow growth of the le- sion until skeletal maturity; however, lesions can regress during childhood and puberty. ${ }^{27}$ Surgical treatment is the standard, and complete resection is often curative, with significantly reduced pain and alleviation of neurological dysfunction. The risk of recurrence is low, and no adjuvant therapy is needed.$^{27}$ In the setting of regrowth, reoperation is recommended. In $10 \%$ of cases, malignant transformation can occur, resulting in osteosarcoma. ${ }^{45}$

\section{Osteosarcoma}

Osteosarcoma is the most common primary malignant bone tumor, and about 5\% of all osteogenic sarcomas are lesions of the spinal column. They are most commonly located in the thoracic and lumbar spine (Fig. 2). ${ }^{50}$ Lesions can present anywhere along the vertebrae, but the most common location is the vertebral body with extension into the spinal canal and pedicles (Fig. 1). Most children diagnosed with osteosarcoma are between 10 and 20 years of
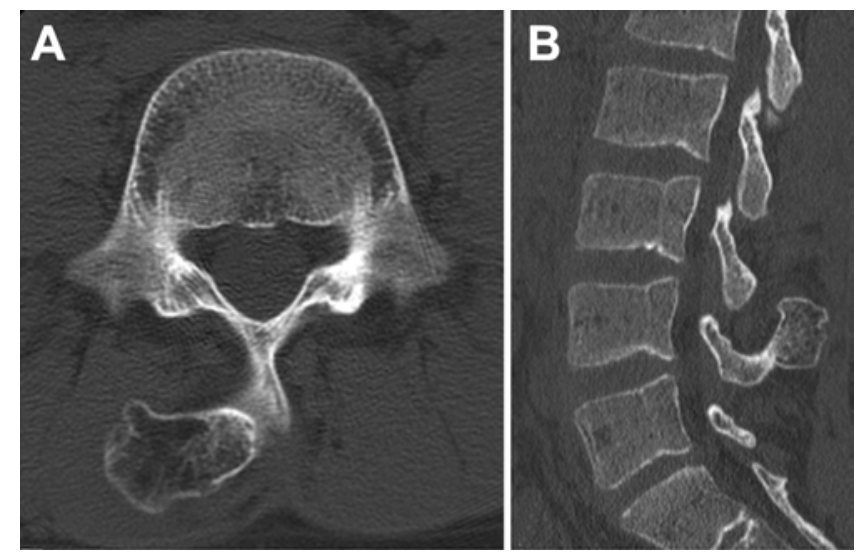

FIG. 5. A 15-year-old boy presented with a lump on his lower back that slowly increased in size over time. Axial (A) and sagittal (B) CT demonstrated a lesion consistent with an osteochondroma emanating from the spinous process of L-4 on the right. The lesion was subsequently resected. The patient had no clinical or radiographic recurrence on follow-up. 
age. ${ }^{11}$ Children can present with pain, soft tissue swelling over the lesion, or neurological dysfunction; in fact, up to $40 \%$ have neurological abnormalities on presentation. ${ }^{50}$

Imaging findings in osteosarcoma can vary. Plain radiographs can demonstrate a radiolucent, radiodense, or mixed radiolucent-radiodense destructive lesion. ${ }^{27}$ Magnetic resonance imaging can be helpful in narrowing the diagnosis: the bony component of the tumor is hypointense on T1- and T2-weighted imaging, whereas the adjacent soft tissue mass is hyperintense on both T1- and T2-weighted imaging (Fig. 6). ${ }^{27} \mathrm{~A}$ soft tissue mass invading the spinal canal can be present in more than $80 \%$ of patients with osteosarcoma, ${ }^{11}$ so neurosurgeons should maintain a high index of suspicion when coming across such findings.

The surgical treatment for osteosarcoma of the spine is based on location and the ability to safely achieve wide margins. ${ }^{27}$ After tissue diagnosis is obtained, through either en bloc resection or biopsy, neoadjuvant chemotherapy is administered to treat the primary tumor and metastatic lesions. ${ }^{27}$ Because of the anatomical constraints of the spine and tumor blood supply, surgical planning is of the utmost importance. Use of the Weinstein-Boriani-Biagini (WBB) and Enneking spinal tumor staging systems can assist in surgical planning. ${ }^{20,28}$ The WBB staging system divides the spine segments with the tumor into 12 radiating zones and also takes into account the transverse plane and 5 layers (A to $\mathrm{E}$, from the paravertebral extraosseous region to the area of dural involvement) of the spine segment..$^{20,29}$ Enneking et al. ${ }^{28}$ also proposed staging based on tumor compartments and anatomical barriers, a system that was later adopted to the spine by Tomita et al., ${ }^{96}$ who concluded that one vertebra could be considered as a single oncological compartment and its surrounding tissues (ligaments, periosteum, and cartilage) as barriers. ${ }^{29,96}$ These tools are the hallmarks of oncological spine surgery and should be considered when planning surgery on a primary or metastatic osseous tumor in the pediatric spine.

Although the combination of chemotherapy and localcontrol surgery has improved survival rates for children with osteosarcoma, 7,76 the 5 -year mortality rate remains high for patients with osteosarcoma of the spine, with a median overall survival of 29.5 months. ${ }^{88}$ Ozaki et al. ${ }^{76}$ demonstrated a median survival of 23 months, with 3 of 22 patients surviving without disease for $>6$ years after treatment; these authors found that patients with primary metastases, large tumors, and sacral tumors had lower overall survival.

\section{Aneurysmal Bone Cyst}

Aneurysmal bone cysts represent $1.4 \%$ of all primary bony tumors ${ }^{25}$ and the spinal column is affected anywhere from $3 \%$ to $20 \%$ of the time..$^{25,100}$ Patients with aneurysmal bone cysts usually present within the first 2 decades of life (Table 1) 27,100 and have symptoms of localized pain that worsens with activity. Neurological symptoms can occur as the lesion compresses the neural structures; pathological fractures can also occur, leading to spinal instability as normal vertebral elements are infiltrated and replaced. ${ }^{45}$ These lesions have a predilection for the posterior elements of the vertebrae $(70 \%)$ and most commonly occur in the lumbar spine (Table 3), 35,47,65,78 although they can also occur
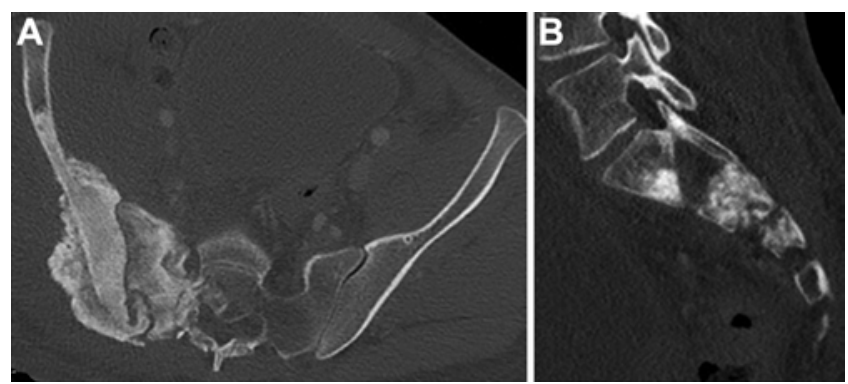

FIG. 6. A 15-year-old boy presented with worsening pelvic pain. A: Axial CT showed a lesion consistent with osteosarcoma involving the right sacrum and iliac with osteoid matrix and lobular contours with areas of calcification in the sacrum. B: Sagittal reformat demonstrating lateral extension of the tumor abutting the right S-1 and S-2 nerve roots. The patient had metastatic disease with pulmonary, thoracic paraspinal, and acetabular lesions. He continues to have disease progression despite treatment with chemotherapy and palliative radiation.

in the thoracic and cervical spine (Figs. 7 and 8). They can extend into the pedicle and vertebral body and span multiple vertebral levels. ${ }^{22}$ On occasion, aneurysmal bone cysts can be associated with additional bone lesions, including Langerhans cell histiocytosis, chondroblastoma, giant cell tumor, and osteosarcoma. ${ }^{27}$ In such cases, the patients will require long-term follow-up even after treatment.

Plain radiographs often show an expansile, radiolucent lesion. Magnetic resonance imaging demonstrates a multiloculated, septated expansile lesion with obvious fluid-fluid levels that generate hypointense signal on T1-weighted images and hyperintense signal on T2-weighted images (Fig. 7). ${ }^{27}$ The fluid-fluid levels in the central region of the trabeculae are surrounded by an "eggshell" rim of cortical bone. ${ }^{45}$ Computed tomography can also be useful in determining the extent of bone involvement.

Surgical intervention includes obtaining a tissue diagnosis, although this is often not necessary because of the lesion's unique appearance on preoperative imaging, followed by complete resection, and stabilization, if necessary based on tumor location. Aneurysmal bone cysts are considered benign but locally aggressive lesions. ${ }^{47}$ Histologically, the lesions have a hemorrhagic component with findings of hemosiderin-laden macrophages, multinucleated giant cells, fibrous tissue, and expansion of the cortical margins. ${ }^{45}$

Historically, surgical treatment involved only intralesional curettage, but this was followed by recurrence rates up to $60 \% .{ }^{19,22,47,78}$ Additional intraoperative steps-cauterization of the osseous cyst wall, extended curettage with a high-speed diamond bur, and dilute (5\%) phenolization with avoidance of the dura or major blood vessels-have drastically reduced the recurrence rate of intralesional curettage alone. ${ }^{35}$ Although en bloc resection is the goal, it is often not feasible; thus, thorough intralesional curettage should be performed. For larger aneurysmal bone cysts with involvement of multiple vertebral levels and significant ventral extension, preoperative embolization should be considered; although rare, intraoperative death from hemorrhage has been reported. ${ }^{78}$ The use of serial embolization alone has been reported for spinal aneurysmal bone cysts; ${ }^{19}$ however, its use should be reserved for 

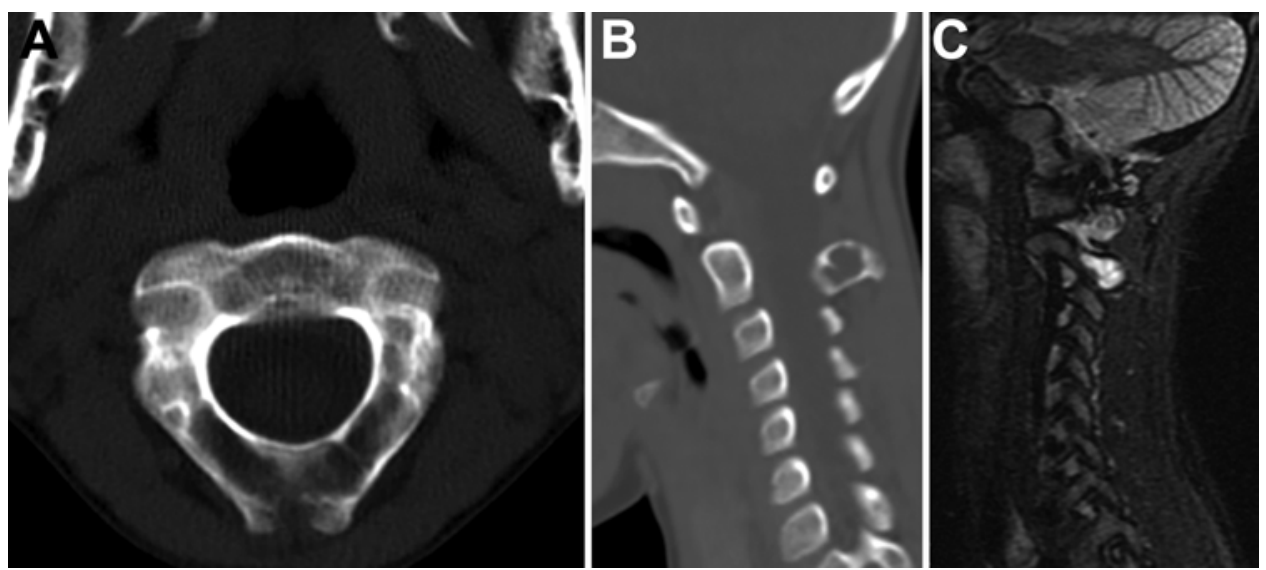

FIG. 7. A 7-year-old boy who presented with neck pain that worsened with activity was found to have an aneurysmal bone cyst at C-2 on imaging. A: Axial CT showed an expansile lytic lesion of C-2 involving both laminae and the left pedicle. B: Sagittal CT demonstrated normal height of the vertebral bodies and no associated soft tissue mass. C: Sagittal T2-weighted MR image demonstrated an expansile lesion in the posterior bony elements of C-2 with layering fluid-fluid level. The patient underwent C-2 laminectomy for removal of the lesion. One year postresection, he has had no radiographic recurrence.

lesions located in areas that are difficult to access surgically. After removal of the lesion, instrumentation and fusion may be necessary to maintain spinal alignment and stability (Fig. 8).

Residual aneurysmal bone cysts have a high propensity for progressive enlargement with the potential for symptom recurrence..$^{45}$ The presence of residual or recurrent aneurysmal bone cyst after an initial surgical attempt is not uncommon, with rates as high as $14 \% .^{75,78,109}$ Recurrence can be delayed, but the most common scenario is recurrence within 6 months. ${ }^{78}$ Even in the setting of recurrent or residual aneurysmal bone cyst, the preferred treatment modality is surgery. The use of denosumab, a human monoclonal antibody that inhibits osteoclast function by inhibiting the cytokine receptor activator of the nuclear factor-kappa B ligand (RANKL) and is approved for the treatment of giant cell tumors of the bone (see below), has also been reported in 2 children with recurrent aneurysmal bone cysts after surgery ${ }^{61}$ and 1 adult with a large sacral aneurysmal bone cyst. ${ }^{92}$ All 3 patients had pain relief with no side effects and showed no progression of the lesion on follow-up. As this represents a potential novel treatment option, further study is warranted.

\section{Eosinophilic Granuloma}

Eosinophilic granuloma is an umbrella term that encompasses a heterogeneous group of conditions characterized by the presence of a benign destructive osteolytic lesion with proliferation of a dendritic cell type called Langerhans cells, which are antigen-presenting cells. Syndromes that encompass eosinophilic granuloma include Langerhans cell histiocytosis (histiocytosis X), HandSchüller-Christian disease, and Letterer-Siwe disease. Solitary eosinophilic granuloma can involve any bones but most commonly occurs in the skull (calvaria and temporal bones), ribs, mandible, pelvis, and spine. ${ }^{40}$ Involvement of the vertebral column occurs in 10\%-15\% of children with eosinophilic granuloma, ${ }^{64}$ and the thoracic and cervical segments are the most common locations. ${ }^{30,34,82,107}$ Eosinophilic granuloma can occur at any age, but most often occurs in children younger than 15 years of age (Table 1), with males being more affected than females. ${ }^{21}$ Spinal eo-
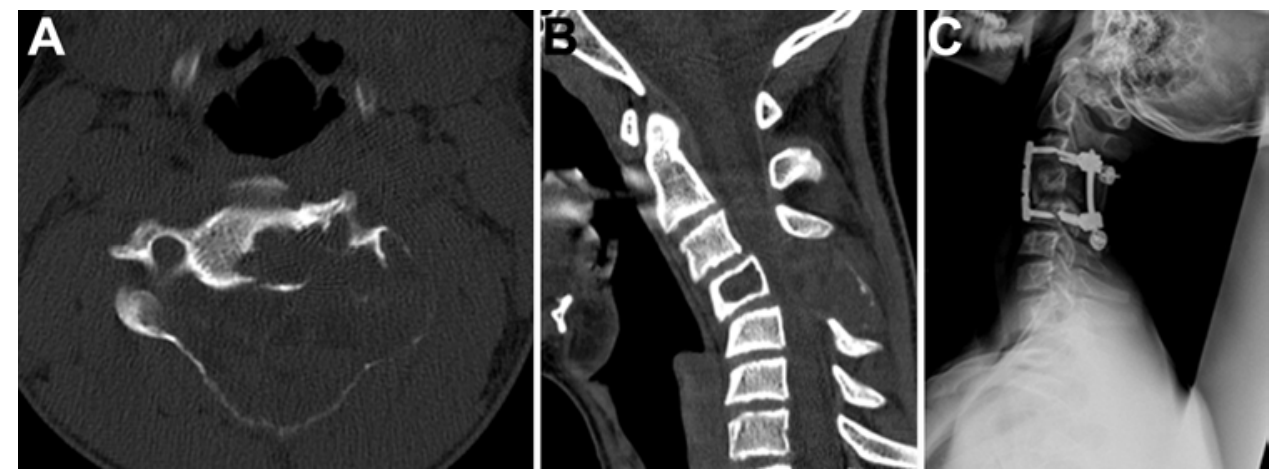

FIG. 8. A 13-year-old boy who presented with neck and shoulder pain and a large aneurysmal bone cyst at C-4. A: Axial CT demonstrating an expansile lytic lesion of C-4 including body and neural arch elements. B: Sagittal CT showed $27^{\circ}$ focal kyphosis at the C4-5 level. C: Lateral postoperative radiograph following C-4 laminectomy for excision of the aneurysmal bone cyst, followed by posterior instrumentation from C-3 to C-5, then an anterior C-4 corpectomy with C3-5 fusion. Cervical spine radiographs at 3 years revealed a stable appearance of the cervical spine. The patient has had no recurrence and has required no further treatment. 
sinophilic granuloma can present as pain and a restricted range of motion; ${ }^{57}$ however, neurological deficits occur rarely. ${ }^{13,40}$ Patients who present with neurological symptoms can have weakness or pain secondary to nerve root compression from vertebral body collapse or, in severe cases, can have early progressive myelopathy with gait dysfunction.

Radiographic findings in eosinophilic granuloma range from lytic lesions to vertebral collapse (partial to complete collapse) with normal adjacent disc spaces and lack of soft tissue mass or extraaxial spread. ${ }^{34}$ The vertebral collapse is secondary to the osteolytic lesion of the underlying bone and can progress to vertebra plana (Fig. 9).${ }^{60}$ Computed tomography and plain radiography can demonstrate bony destruction. Magnetic resonance imaging can be performed to further characterize these lesions and evaluate for soft tissue involvement. Flexion-extension radiographs of the spine can provide insight into the presence of a kyphotic spinal deformity secondary to the lesion. Additionally, a skeletal survey can be used to search for other lesions associated with multifocal disease. ${ }^{32}$

Management of spine lesions is individualized and tailored to clinical and radiographic presentation. Bertram et al. ${ }^{13}$ reported that most cases of spine involvement included in a meta-analysis were managed with observation. Surgical intervention with excision, segmental fusion, or internal fixation is reserved for patients with neurological deficit, spinal instability, and noncompliance with external bracing. Open or CT-guided biopsy is performed when definitive diagnosis is sought. Chemotherapy is only recommended for disseminated forms of eosinophilic granuloma. ${ }^{46}$ Radiotherapy is no longer recommended because of the long-term risks of the development of malignant tumors in the radiation field, although radiotherapy is considered by some physicians in the treatment of solitary bony lesions in children. ${ }^{31}$

\section{Giant Cell Tumor}

Giant cell tumors represent $5 \%$ of all primary bone tumors. ${ }^{97}$ Although they do not typically present until the 3rd or 4 th decade of life, ${ }^{27}$ they can very rarely occur in children. There is an overall predilection for females. ${ }^{45}$ Pain, localized swelling, and tenderness are the most common presenting symptoms, although spinal cord compression from tumor extension can occur as well. ${ }^{27}$ Giant cell tumors most commonly present in the sacrum but can also occur in the cervical spine (Fig. 2). ${ }^{45}$ If located in the sacrum, they can enlarge and involve the sacroiliac joints causing secondary referred pain. Those outside of the sacrum often involve the vertebral body, ${ }^{45}$ but vertebral lesions are rare, especially in children. ${ }^{89}$

Giant cell tumors are benign but locally aggressive lesions. Radiographs demonstrate an area of expansile focal destruction that projects as a "radiolucent zone" without a cortical margin. Computed tomography and MRI can be helpful adjuncts in diagnosis and for preoperative staging. ${ }^{20}$ Giant cell tumors are contrast-enhancing expansile lesions on MRI (Fig. 10). Once the diagnosis of giant cell tumor is suspected, chest imaging should be performed to rule out pulmonary lesions, which can be present in up to $9 \%$ of patients with a giant cell tumor. ${ }^{12,54,84}$

The treatment of children with giant cell tumors should
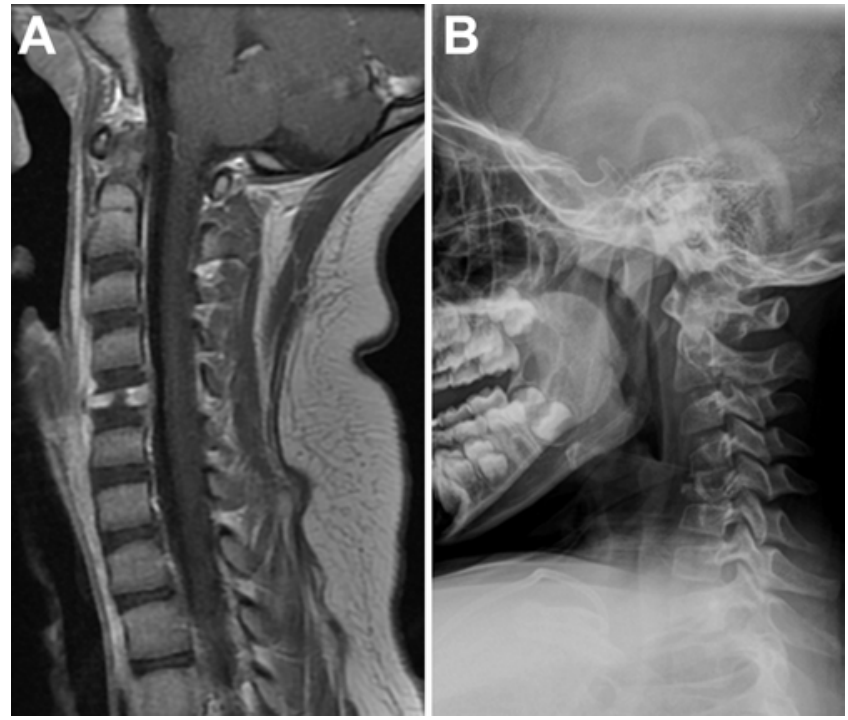

FIG. 9. A 7-year-old girl presented with neck pain and was found to have an eosinophilic granuloma of the C-5 vertebral body. A: Sagittal T1-weighted MR image with gadolinium demonstrated a C-5 pathological fracture with near-complete loss of vertebral height (vertebra plana). B: The patient developed worsening kyphosis (shown), and early myelopathy was treated with a C-5 anterior corpectomy and interbody fusion from C-4 to C-6. Cervical spine radiographs at 2 months after surgery demonstrated stable alignment with osseous fusion from C-4 to C-6.

be primarily surgical. There is a high risk of recurrence $(80 \%)$, so wide resection of the lesion should be undertaken when possible. ${ }^{102}$ When the giant cell tumor is located within or adjacent to the vertebral body, resection can be difficult; thus, the extended curettage technique can be employed, as described above..$^{17,27,44}$ Embolization has also been used as the sole primary treatment in some cases; ${ }^{66}$ more recently, the successful use of bisphosphonates has been reported..$^{37,110}$ Radiation therapy can be used, but given the overall benign histological profile of giant cell tumors, it should be reserved for patients with inoperable lesions. ${ }^{74}$ The use of denosumab, a monoclonal antibody, has been described for the treatment of giant cell tumors of the bone. ${ }^{106}$ Denosumab targets RANKL, which is expressed by giant cells and is the cause of the aggressive osteolytic nature of the tumor. In an open-label phase 2 study of patients with unresectable giant cell tumors who received denosumab, $30(86 \%)$ of 35 demonstrated tumor response to the drug via histology or radiology. ${ }^{95}$ The antibody was approved by the US Food and Drug Administration for the treatment of unresectable giant cell tumors of bone in adults and skeletally mature adolescents, or when resection is unsafe or will cause significant morbidity; ${ }^{2}$ thus, it can be an option for difficult-to-access lesions in the vertebral column.

As with the other primary osseous lesions of the spine, instrumentation should be used in the setting of mechanical instability; caution should be exercised in choosing the hardware to minimize artifacts on postoperative imaging studies. Close follow-up is important to monitor for signs of recurrent tumor, especially in patients with locally aggressive disease and residual tumor burden after surgery. 

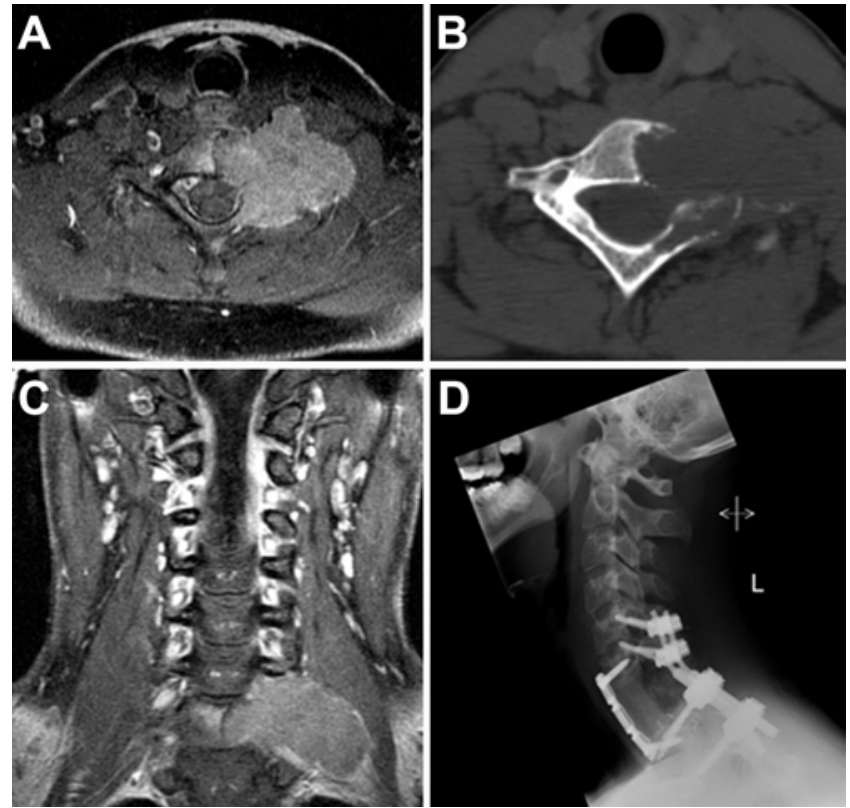

FIG. 10. A 16-year-old boy presented with left arm numbness. Axial (A) and coronal (B) T1-weighted MR images with gadolinium demonstrated a mass centered around the left side of C-7 involving the vertebral body and invasion into the surrounding structures including trunks of the lower brachial plexus. Axial CT (C) showed an erosive soft tissue mass with destruction of the left C-7 vertebral body, pedicle, and lamina. The lesion (D), diagnosed as giant cell tumor, was removed in a 2-stage procedure consisting of posterior resection with $\mathrm{C} 6-\mathrm{T} 1$ laminectomies and posterior spinal fusion from C-5 to T-2 with resection of tumor invading into the brachial plexus, followed by an anterior C-7 corpectomy and anterior cervical fusion from C-6 to T-1. Computed tomography of the cervical spine and soft tissue 7 years after surgery showed no recurrence; no further treatment was necessary.

\section{Ewing Sarcoma}

Nearly $75 \%$ of cases of Ewing sarcoma occur in children between the ages of 5 and 15 years..$^{63}$ Ewing sarcoma is the most common primary malignant bone tumor seen in the pediatric spine. It is thought that between $3.5 \%$ and $10 \%$ of all cases of Ewing sarcoma originate in the spine. ${ }^{99,104}$ Spinal lesions can be primary or metastatic. The sacrum is the most common location for these lesions to occur, followed by the lumbar and thoracic spine, and rarely the cervical spine. ${ }^{99}$

Venkateswaran et al. ${ }^{99}$ presented evidence that the most commonly reported presenting symptoms were pain (9\%) and neurological deficit (9\%). In some children, there can be an associated tender soft tissue mass. Like children with other malignancies, children with spinal Ewing sarcoma can have constitutional symptoms including weight loss and fever; serum inflammatory markers are also elevated in most children. ${ }^{27}$

Although Ewing sarcoma typically has a characteristic moth-eaten appearance with a large soft tissue mass in long bones and aggressive periosteal new bone formation with an "onion skin" appearance, its appearance in the spine is not as distinguishing. ${ }^{27}$ Radiographs or CT imaging may show vertebra plana with an associated soft tissue mass. Magnetic resonance imaging can detect bone lesions but is mostly used in identifying and evaluating the
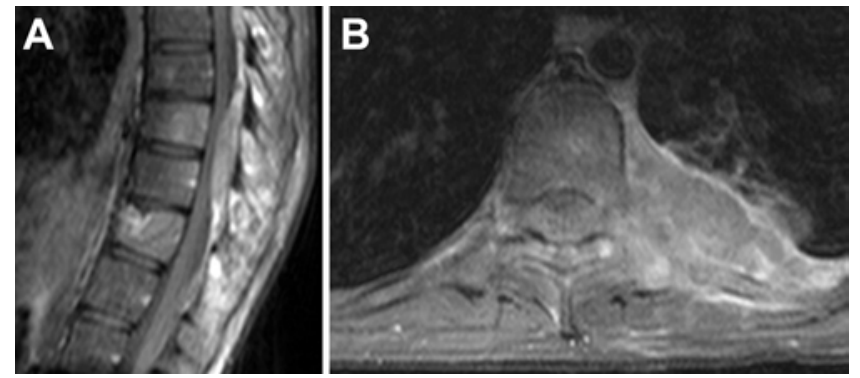

FIG. 11. A 17-year-old girl presented with progressive back pain and difficulty walking. A: Sagittal T1-weighted MR image with gadolinium showed a T9-10 epidural mass causing cord compression. B: Axial T1-weighted MR image with gadolinium demonstrated bony destruction of the pedicle of T-9 on the left side and associated large left-sided paraspinal mass. The patient underwent emergent T7-10 laminectomies for resection of the extradural tumor identified on histopathology as Ewing sarcoma. She is currently undergoing chemotherapy and radiation treatment.

extent of soft tissue involvement and epidural compression (Fig. 11). ${ }^{27}$ Grossly, tumors often appear firm, gray, and friable with distinct areas of hemorrhage and necrosis. ${ }^{45}$

The treatment for Ewing sarcoma has evolved significantly. Current treatment recommendations include biopsy with initial chemotherapy and radiation therapy for highgrade malignancies. Salvage surgery for residual tumor can be considered based on location and prognosis. Spinal resection and reconstruction (spondylectomy) can be considered following chemotherapy to reduce the risk of local recurrence, with improved long-term survival compared with that following intralesional excision or radiation therapy: ${ }^{26}$ cases involving the sacrum may involve pelvic fixation and reconstruction. In the case of lower-grade tumors, surgery followed by adjuvant chemotherapy and radiation is the current treatment standard..$^{42,111}$

For surgical planning, location is key and plays an important role in survival. For instance, lesions that present in the sacrum are often large prior to diagnosis, making en bloc resection technically challenging. ${ }^{9}$ Lesions of the mobile spine, however, often present earlier and are more amenable to resection. For Ewing sarcoma, subtotal or partial resection should be avoided; en bloc resection with negative tumor margins should be the surgical goal.,15

Unfortunately, metastatic disease can be present in 25\% of patients at presentation. The most common locations for metastatic spread include the lungs, other osseous sites, the lymphatic system, the brain, and the abdominal viscera. ${ }^{7,99}$ Although it is an aggressive lesion, Ewing sarcoma has responded more favorably than other sarcomas to radiation, and many patients can respond well to external beam radiation. ${ }^{58}$ Survival for patients with Ewing sarcoma of the vertebral column is better than that for patients with osteosarcoma; children with an isolated vertebral column lesion have a median survival of 90 months, and those with evidence of metastatic disease have a median survival of 20 months. The 5-year overall survival rate is $41 \% .^{72}$

Favorable factors for survival in Ewing sarcoma include age $<10$ years, tumor volume $<100 \mathrm{ml}$, positive response to chemotherapy, and en bloc resection..$^{15}$ Negative factors include metastatic disease, tumor larger than $8 \mathrm{~cm}$, elevated white blood cell count or erythrocyte sedimentation 
rate, and poor response to chemotherapy $(<90 \%$ reduction of tumor volume). ${ }^{105}$

\section{Additional Tumors}

Although the focus of this review is primary osseous tumors of the pediatric spinal column, several other pathologies can present with symptoms and neurological deficits similar to those of the aforementioned lesions.

\section{Neuroblastoma}

Neuroblastoma stands as the most common extracranial solid tumor in children, and the most common neoplasm in infants. ${ }^{45}$ It also represents the most common malignant tumor of the spine and spinal cord treated by neurosurgeons. Lesions arise from the sympathetic nervous system, adrenal glands, and ganglia of the thoracic, cervical, and pelvic regions and grow to a large size before there is spinal involvement. These lesions typically encroach on neural foramina and result in a dumbbell configuration. ${ }^{45}$ Metastatic spread of neuroblastoma with epidural compression of the vertebral column can occur; thus, in a patient with a significant history and evidence of soft tissue compression of the epidural space, neuroblastoma should be considered. The lesion is sensitive to chemotherapy and radiation, but surgical decompression can be considered in the setting of acute neurological decline. Parikh et al. ${ }^{79}$ reported on 22 patients, 19 of whom attained a favorable outcome and long-term survival. Sandberg et al. ${ }^{87}$ concluded that high-risk neuroblastoma patients with high-grade spinal cord compression may respond to chemotherapy, but a percentage will require surgical decompression for progressive neurological deficits. For patients at low risk, the 5-year survival rate is greater than 95\%; for those in the intermediate-risk group, the rate is between $90 \%$ and 95\%; and for those in the high-risk group, the rate is between $40 \%$ and $50 \% .^{5}$ The decision to pursue surgery, however, should be balanced with the timing and degree of symptoms, the risk for postoperative deformity, and the chemo- and radiosensitivity of the tumor. ${ }^{53}$

\section{Rhabdomyosarcoma}

Rhabdomyosarcomas account for $8 \%$ of pediatric solid tumors. ${ }^{45}$ When there is spinal involvement, this lesion occurs in a manner similar to neuroblastoma, that is, a dumbbell-shaped tumor with a large paraspinal soft tissue mass that can present with epidural compression..$^{45}$ Rhabdomyosarcoma is sensitive to chemotherapy and radiation, so surgery should be reserved for patients with neurological deficits. ${ }^{24}$

\section{Chordoma}

Chordomas are locally aggressive lesions that arise because of malignant transformation of notochordal elements, the embryological source of the nucleus pulposus. They are rare in children but can arise primarily in the skull base at the spheno-occipital junction, occasionally in the mobile portion of the spine, and infrequently in the sacrococcygeal region (Fig. 2). ${ }^{91}$ Because of the cell of origin, there is inherent involvement of the vertebral body and associated osteolysis and a large associated soft tis- sue mass. ${ }^{45}$ Surgery for chordomas includes en bloc resection with tumor-free margins; proton beam radiotherapy is used for residual or recurrent tumor. ${ }^{16}$ For chordomas located at the skull base, radical excision is the treatment of choice. Occipitocervical fusion may be necessary, depending on tumor location and infiltration at the time of diagnosis, ${ }^{10}$ if there is a risk of mechanical instability. Chordomas involving the sacrococcygeal region may also require stabilization if radical resection is pursued, but it may be difficult and could necessitate pelvic fixation and reconstruction. The use of imatinib in locally advanced chordoma has been described, with a $>70 \%$ arrest of tumor growth, a median duration of response of 10 months, and $>20 \%$ of patients with the absence of progression at 18 months. ${ }^{49}$ Sunitinib and imatinib have also been used, ${ }^{62}$ and there are additional molecular therapies on the horizon. The 5-year survival rate is approximately $50 \% .{ }^{83,93}$

\section{Conclusions}

Although primary osseous spinal column tumors are rare in children and young adults, a high index of suspicion should be maintained when evaluating children with back pain either with or without neurological dysfunction. Primary osseous lesions of the pediatric spine can be benign or malignant and commonly present diagnostic and therapeutic challenges. A thorough understanding of the clinical and radiographic findings in each of these pathological conditions can help facilitate diagnosis and appropriate treatment. Surgical decision making can be guided by a complete understanding of the pathology. When properly performed, surgery can often lead to a complete resolution of pain and neurological symptoms.

\section{Acknowledgments}

The authors thank Kristin Kraus, MSc, for editorial assistance with this paper.

\section{References}

1. Akbarnia BA, Rooholamini SA: Scoliosis caused by benign osteoblastoma of the thoracic or lumbar spine. J Bone Joint Surg Am 63:1146-1155, 1981

2. Akeda K, Kasai Y, Sakakibara T, Matsumine A, Takegami $\mathrm{N}$, Yamada J, et al: Effect of denosumab on recurrent giant cell reparative granuloma of the lumbar spine. Spine (Phila Pa 1976) 40:E601-E608, 2015

3. Albrecht S, Crutchfield JS, SeGall GK: On spinal osteochondromas. J Neurosurg 77:247-252, 1992

4. Amacher AL, Eltomey A: Spinal osteoblastoma in children and adolescents. Childs Nerv Syst 1:29-32, 1985

5. American Cancer Society: Survival rates for neuroblastoma based on risk groups. Cancer.org. (http://www.cancer.org/ cancer/neuroblastoma/detailedguide/neuroblastoma-survival-rates) [Accessed June 9, 2016]

6. Antunes NL: Back and neck pain in children with cancer. Pediatr Neurol 27:46-48, 2002

7. Arndt CA, Crist WM: Common musculoskeletal tumors of childhood and adolescence. N Engl J Med 341:342-352, 1999

8. Azouz EM, Kozlowski K, Marton D, Sprague P, Zerhouni A, Asselah F: Osteoid osteoma and osteoblastoma of the spine in children. Report of 22 cases with brief literature review. Pediatr Radiol 16:25-31, 1986 
9. Bacci G, Boriani S, Balladelli A, Barbieri E, Longhi A, Alberghini M, et al: Treatment of nonmetastatic Ewing's sarcoma family tumors of the spine and sacrum: the experience from a single institution. Eur Spine J 18:1091-1095, 2009

10. Barrenechea IJ, Perin NI, Triana A, Lesser J, Costantino P, Sen C: Surgical management of chordomas of the cervical spine. J Neurosurg Spine 6:398-406, 2007

11. Barwick KW, Huvos AG, Smith J: Primary osteogenic sarcoma of the vertebral column: a clinicopathologic correlation of ten patients. Cancer 46:595-604, 1980

12. Bertoni F, Present D, Sudanese A, Baldini N, Bacchini P, Campanacci M: Giant-cell tumor of bone with pulmonary metastases. Six case reports and a review of the literature. Clin Orthop Relat Res (237):275-285, 1988

13. Bertram C, Madert J, Eggers C: Eosinophilic granuloma of the cervical spine. Spine (Phila Pa 1976) 27:1408-1413, 2002

14. Blaskiewicz DJ, Sure DR, Hedequist DJ, Emans JB, Grant F, Proctor MR: Osteoid osteomas: intraoperative bone scanassisted resection. Clinical article. J Neurosurg Pediatr 4:237-244, 2009

15. Boriani S, Amendola L, Corghi A, Cappuccio M, Bandiera S, Ferrari S, et al: Ewing's sarcoma of the mobile spine. Eur Rev Med Pharmacol Sci 15:831-839, 2011

16. Boriani S, Bandiera S, Biagini R, Bacchini P, Boriani L, Cappuccio M, et al: Chordoma of the mobile spine: fifty years of experience. Spine (Phila Pa 1976) 31:493-503, 2006

17. Boriani S, Bandiera S, Casadei R, Boriani L, Donthineni R, Gasbarrini A, et al: Giant cell tumor of the mobile spine: a review of 49 cases. Spine (Phila Pa 1976) 37:E37-E45, 2012

18. Boriani S, Capanna R, Donati D, Levine A, Picci P, Savini R: Osteoblastoma of the spine. Clin Orthop Relat Res (278):37-45, 1992

19. Boriani S, De Iure F, Campanacci L, Gasbarrini A, Bandiera S, Biagini R, et al: Aneurysmal bone cyst of the mobile spine: report on 41 cases. Spine (Phila Pa 1976) 26:27-35, 2001

20. Boriani S, Weinstein JN, Biagini R: Primary bone tumors of the spine. Terminology and surgical staging. Spine (Phila Pa 1976) 22:1036-1044, 1997

21. Broadbent V, Egeler RM, Nesbit ME Jr: Langerhans cell histiocytosis - clinical and epidemiological aspects. Br J Cancer Suppl 23:S11-S16, 1994

22. Capanna R, Albisinni U, Picci P, Calderoni P, Campanacci M, Springfield DS: Aneurysmal bone cyst of the spine. J Bone Joint Surg Am 67:527-531, 1985

23. Capanna R, Boriani S, Mabit C, Donati D, Savini R: [Osteoid osteoma of the spine. The experience of the Rizzoli Institute.] Rev Chir Orthop Repar Appar Mot 77:545-550, 1991 (Fr)

24. Crist WM, Anderson JR, Meza JL, Fryer C, Raney RB, Ruymann FB, et al: Intergroup rhabdomyosarcoma studyIV: results for patients with nonmetastatic disease. J Clin Oncol 19:3091-3102, 2001

25. Dahlin DC: Bone Tumors: General Aspects and Data on 6,221 Cases, ed 3. Springfield, IL: Charles C Thomas, 1978

26. Dini LI, Mendonça R, Gallo P: Primary Ewings sarcoma of the spine: case report. Arq Neuropsiquiatr 64 (3A):654659, 2006

27. Dormans JP, Moroz L: Infection and tumors of the spine in children. J Bone Joint Surg Am 89 (Suppl 1):79-97, 2007

28. Enneking WF, Spanier SS, Goodman MA: A system for the surgical staging of musculoskeletal sarcoma. 1980. Clin Orthop Relat Res (415):4-18, 2003

29. Feng D, Yang X, Liu T, Xiao J, Wu Z, Huang Q, et al: Osteosarcoma of the spine: surgical treatment and outcomes. World J Surg Oncol 11:89, 2013
30. Floman Y, Bar-On E, Mosheiff R, Mirovsky Y, Robin GC, Ramu N: Eosinophilic granuloma of the spine. J Pediatr Orthop B 6:260-265, 1997

31. French Langerhans' Cell Histiocytosis Study Group: A multicentre retrospective survey of Langerhans' cell histiocytosis: 348 cases observed between 1983 and 1993. Arch Dis Child 75:17-24, 1996

32. Gadner H, Minkov M, Grois N, Pötschger U, Thiem E, Aricò $\mathrm{M}$, et al: Therapy prolongation improves outcome in multisystem Langerhans cell histiocytosis. Blood 121:50065014, 2013

33. Garg S, Dormans JP: Tumors and tumor-like conditions of the spine in children. J Am Acad Orthop Surg 13:372381,2005

34. Garg S, Mehta S, Dormans JP: Langerhans cell histiocytosis of the spine in children. Long-term follow-up. J Bone Joint Surg Am 86-A: 1740-1750, 2004

35. Garg S, Mehta S, Dormans JP: Modern surgical treatment of primary aneurysmal bone cyst of the spine in children and adolescents. J Pediatr Orthop 25:387-392, 2005

36. Gasbarrini A, Cappuccio M, Bandiera S, Amendola L, van Urk P, Boriani S: Osteoid osteoma of the mobile spine: surgical outcomes in 81 patients. Spine (Phila Pa 1976) 36:2089-2093, 2011

37. Gille O, de Azevedo Oliveira B, Guerin P, Lepreux S, Richez C, Vital JM: Regression of giant cell tumor of the cervical spine with bisphosphonate as single therapy. Spine (Phila Pa 1976) 37:E396-E399, 2012

38. Ginsburg GM, Bassett GS: Back pain in children and adolescents: evaluation and differential diagnosis. J Am Acad Orthop Surg 5:67-78, 1997

39. Greenberg M: Handbook of Neurosurgery, ed 7. New York: Thieme, 2010

40. Greenlee JD, Fenoy AJ, Donovan KA, Menezes AH: Eosinophilic granuloma in the pediatric spine. Pediatr Neurosurg 43:285-292, 2007

41. Greenspan A, Remagen W: Differential Diagnosis of Tumors and Tumor-Like Lesions of Bones and Joints. Philadelphia: Lippincott-Raven, 1998, pp 25-122

42. Grubb MR, Currier BL, Pritchard DJ, Ebersold MJ: Primary Ewing's sarcoma of the spine. Spine (Phila Pa 1976) 19:309-313, 1994

43. Hadjipavlou AG, Tzermiadianos MN, Kakavelakis KN, Lander P: Percutaneous core excision and radiofrequency thermo-coagulation for the ablation of osteoid osteoma of the spine. Eur Spine J 18:345-351, 2009

44. Harrop JS, Schmidt MH, Boriani S, Shaffrey CI: Aggressive "benign" primary spine neoplasms: osteoblastoma, aneurysmal bone cyst, and giant cell tumor. Spine (Phila Pa 1976) 34 (22 Suppl):S39-S47, 2009

45. Harter D, Weiner H: Spine tumors, in Albright AL, Pollack I, Adelson P (eds): Principles and Practice of Pediatric Neurosurgery, ed 3. New York: Thieme, 2014, pp 721-734

46. Haupt R, Minkov M, Astigarraga I, Schäfer E, Nanduri V, Jubran R, et al: Langerhans cell histiocytosis (LCH): guidelines for diagnosis, clinical work-up, and treatment for patients till the age of 18 years. Pediatr Blood Cancer 60: $175-184,2013$

47. Hay MC, Paterson D, Taylor TK: Aneurysmal bone cysts of the spine. J Bone Joint Surg Br 60-B:406-411, 1978

48. Healey JH, Ghelman B: Osteoid osteoma and osteoblastoma. Current concepts and recent advances. Clin Orthop Relat Res (204): 76-85, 1986

49. Hindi N, Casali PG, Morosi C, Messina A, Palassini E, Pilotti S, et al: Imatinib in advanced chordoma: a retrospective case series analysis. Eur J Cancer 51:2609-2614, 2015

50. Ilaslan H, Sundaram M, Unni KK, Shives TC: Primary vertebral osteosarcoma: imaging findings. Radiology 230:697702,2004 
51. Janin Y, Epstein JA, Carras R, Khan A: Osteoid osteomas and osteoblastomas of the spine. Neurosurgery 8:31-38, 1981

52. Kan P, Schmidt MH: Osteoid osteoma and osteoblastoma of the spine. Neurosurg Clin N Am 19:65-70, 2008

53. Katzenstein HM, Kent PM, London WB, Cohn SL: Treatment and outcome of 83 children with intraspinal neuroblastoma: the Pediatric Oncology Group experience. J Clin Oncol 19:1047-1055, 2001

54. Kay RM, Eckardt JJ, Seeger LL, Mirra JM, Hak DJ: Pulmonary metastasis of benign giant cell tumor of bone. Six histologically confirmed cases, including one of spontaneous regression. Clin Orthop Relat Res (302):219-230, 1994

55. Keim HA, Reina EG: Osteoid-osteoma as a cause of scoliosis. J Bone Joint Surg Am 57:159-163, 1975

56. Kelley SP, Ashford RU, Rao AS, Dickson RA: Primary bone tumours of the spine: a 42-year survey from the Leeds Regional Bone Tumour Registry. Eur Spine J 16:405-409, 2007

57. Kilpatrick SE, Wenger DE, Gilchrist GS, Shives TC, Wollan PC, Unni KK: Langerhans' cell histiocytosis (histiocytosis $\mathrm{X})$ of bone. A clinicopathologic analysis of 263 pediatric and adult cases. Cancer 76:2471-2484, 1995

58. Kim HJ, McLawhorn AS, Goldstein MJ, Boland PJ: Malignant osseous tumors of the pediatric spine. J Am Acad Orthop Surg 20:646-656, 2012

59. Kirchner B, Hillmann A, Lottes G, Sciuk J, Bartenstein P, Winkelmann W, et al: Intraoperative, probe-guided curettage of osteoid osteoma. Eur J Nucl Med 20:609-613, 1993

60. Lam S, Reddy GD, Mayer R, Lin Y, Jea A: Eosinophilic granuloma/Langerhans cell histiocytosis: pediatric neurosurgery update. Surg Neurol Int 6 (Suppl 17):S435-S439, 2015

61. Lange T, Stehling C, Fröhlich B, Klingenhöfer M, Kunkel P, Schneppenheim R, et al: Denosumab: a potential new and innovative treatment option for aneurysmal bone cysts. Eur Spine J 22:1417-1422, 2013

62. Lebellec L, Aubert S, Zaïri F, Ryckewaert T, Chauffert B, Penel N: Molecular targeted therapies in advanced or metastatic chordoma patients: facts and hypotheses. Crit Rev Oncol Hematol 95:125-131, 2015

63. Leeson MC, Makley JT, Carter JR: Metastatic skeletal disease in the pediatric population. J Pediatr Orthop 5:261267,1985

64. Levine SE, Dormans JP, Meyer JS, Corcoran TA: Langerhans' cell histiocytosis of the spine in children. Clin Orthop Relat Res (323):288-293, 1996

65. Lifeso RM, Younge D: Aneurysmal bone cysts of the spine. Int Orthop 8:281-285, 1985

66. Lin PP, Guzel VB, Moura MF, Wallace S, Benjamin RS, Weber KL, et al: Long-term follow-up of patients with giant cell tumor of the sacrum treated with selective arterial embolization. Cancer 95: 1317-1325, 2002

67. Mark RJ, Poen J, Tran LM, Fu YS, Selch MT, Parker RG: Postirradiation sarcomas. A single-institution study and review of the literature. Cancer 73:2653-2662, 1994

68. Marsh BW, Bonfiglio M, Brady LP, Enneking WF: Benign osteoblastoma: range of manifestations. J Bone Joint Surg Am 57:1-9, 1975

69. Martel J, Bueno A, Nieto-Morales ML, Ortiz EJ: Osteoid osteoma of the spine: CT-guided monopolar radiofrequency ablation. Eur J Radiol 71:564-569, 2009

70. McLeod RA, Dahlin DC, Beabout JW: The spectrum of osteoblastoma. AJR Am J Roentgenol 126:321-325, 1976

71. Menezes AH, Sato Y: Primary tumors of the spine in children - natural history and management. 1990. Pediatr Neurosurg 23:101-114, 1995

72. Mukherjee D, Chaichana KL, Gokaslan ZL, Aaronson O,
Cheng JS, McGirt MJ: Survival of patients with malignant primary osseous spinal neoplasms: results from the Surveillance, Epidemiology, and End Results (SEER) database from 1973 to 2003. J Neurosurg Spine 14:143-150, 2011

73. Myles ST, MacRae ME: Benign osteoblastoma of the spine in childhood. J Neurosurg 68:884-888, 1988

74. Nair MK, Jyothirmayi R: Radiation therapy in the treatment of giant cell tumor of bone. Int J Radiat Oncol Biol Phys 43:1065-1069, 1999

75. Novais EN, Rose PS, Yaszemski MJ, Sim FH: Aneurysmal bone cyst of the cervical spine in children. J Bone Joint Surg Am 93:1534-1543, 2011

76. Ozaki T, Flege S, Liljenqvist U, Hillmann A, Delling G, Salzer-Kuntschik M, et al: Osteosarcoma of the spine: experience of the Cooperative Osteosarcoma Study Group. Cancer 94:1069-1077, 2002

77. Ozaki T, Liljenqvist U, Halm H, Hillmann A, Gosheger G, Winkelmann W: Giant cell tumor of the spine. Clin Orthop Relat Res (401): 194-201, 2002

78. Papagelopoulos PJ, Currier BL, Shaughnessy WJ, Sim FH, Ebsersold MJ, Bond JR, et al: Aneurysmal bone cyst of the spine. Management and outcome. Spine (Phila Pa 1976) 23:621-628, 1998

79. Parikh D, Short M, Eshmawy M, Brown R: Surgical outcome analysis of paediatric thoracic and cervical neuroblastoma. Eur J Cardiothorac Surg 41:630-634, 2012

80. Poleksić ZR, Lalosević VJ, Milinković ZB: Osteoblastoma of the spine. Acta Chir Iugosl 57:63-68, 2010

81. Pollono D, Tomarchia S, Drut R, Ibañez O, Ferreyra M, Cédola J: Spinal cord compression: a review of 70 pediatric patients. Pediatr Hematol Oncol 20:457-466, 2003

82. Raab P, Hohmann F, Kühl J, Krauspe R: Vertebral remodeling in eosinophilic granuloma of the spine. A long-term follow-up. Spine (Phila Pa 1976) 23:1351-1354, 1998

83. Rich TA, Schiller A, Suit HD, Mankin HJ: Clinical and pathologic review of 48 cases of chordoma. Cancer 56:182-187, 1985

84. Rock MG, Pritchard DJ, Unni KK: Metastases from histologically benign giant-cell tumor of bone. J Bone Joint Surg Am 66:269-274, 1984

85. Rosemberg S, Fujiwara D: Epidemiology of pediatric tumors of the nervous system according to the WHO 2000 classification: a report of 1,195 cases from a single institution. Childs Nerv Syst 21:940-944, 2005

86. Saifuddin A, White J, Sherazi Z, Shaikh MI, Natali C, Ransford AO: Osteoid osteoma and osteoblastoma of the spine. Factors associated with the presence of scoliosis. Spine (Phila Pa 1976) 23:47-53, 1998

87. Sandberg DI, Bilsky MH, Kushner BH, Souweidane MM, Kramer K, Laquaglia MP, et al: Treatment of spinal involvement in neuroblastoma patients. Pediatr Neurosurg 39:291-298, 2003

88. Schoenfeld AJ, Hornicek FJ, Pedlow FX, Kobayashi W, Garcia RT, DeLaney TF, et al: Osteosarcoma of the spine: experience in 26 patients treated at the Massachusetts General Hospital. Spine J 10:708-714, 2010

89. Schütte HE, Taconis WK: Giant cell tumor in children and adolescents. Skeletal Radiol 22:173-176, 1993

90. Sharma MC, Arora R, Deol PS, Mahapatra AK, Mehta VS, Sarkar C: Osteochondroma of the spine: an enigmatic tumor of the spinal cord. A series of 10 cases. J Neurosurg Sci 46:66-70, 2002

91. Sibley RK, Day DL, Dehner LP, Trueworthy RC: Metastasizing chordoma in early childhood: a pathological and immunohistochemical study with review of the literature. Pediatr Pathol 7:287-301, 1987

92. Skubitz KM, Peltola JC, Santos ER, Cheng EY: Response of aneurysmal bone cyst to denosumab. Spine (Phila Pa 1976) 40:E1201-E1204, 2015 
93. Staab A, Rutz HP, Ares C, Timmermann B, Schneider R, Bolsi A, et al: Spot-scanning-based proton therapy for extracranial chordoma. Int J Radiat Oncol Biol Phys 81:e489e496, 2011

94. Sundaresan N, Rosen G, Boriani S: Primary malignant tumors of the spine. Orthop Clin North Am 40:21-36, v, 2009

95. Thomas D, Carriere P, Jacobs I: Safety of denosumab in giant-cell tumour of bone. Lancet Oncol 11:815, 2010

96. Tomita K, Kawahara N, Murakami H, Demura S: Total en bloc spondylectomy for spinal tumors: improvement of the technique and its associated basic background. J Orthop Sci 11:3-12, 2006

97. Unni KK, Inwards CY: Dahlin's Bone Tumors: General Aspects and Data on 11,087 Cases, ed 5. Philadelphia: Lippincott-Raven, 1996

98. Vanderschueren GM, Obermann WR, Dijkstra SP, Taminiau AH, Bloem JL, van Erkel AR: Radiofrequency ablation of spinal osteoid osteoma: clinical outcome. Spine (Phila Pa 1976) 34:901-904, 2009

99. Venkateswaran L, Rodriguez-Galindo C, Merchant TE, Poquette CA, Rao BN, Pappo AS: Primary Ewing tumor of the vertebrae: clinical characteristics, prognostic factors, and outcome. Med Pediatr Oncol 37:30-35, 2001

100. Vergel De Dios AM, Bond JR, Shives TC, McLeod RA, Unni KK: Aneurysmal bone cyst. A clinicopathologic study of 238 cases. Cancer 69:2921-2931, 1992

101. Vincent F, Fehlings M: Spinal column tumors, in Bernstein M, Berger M (eds): Neuro-Oncology: The Essentials. New York: Thieme, 2000, pp 391-402

102. Weinstein JN, McLain RF: Primary tumors of the spine. Spine (Phila Pa 1976) 12:843-851, 1987

103. West R: Childhood cancer mortality: international comparisons 1955-1974. World Health Stat Q 37:98-127, 1984

104. Whitehouse GH, Griffiths GJ: Roentgenologic aspects of spinal involvement by primary and metastatic Ewing's tumor. J Can Assoc Radiol 27:290-297, 1976

105. Wilkins RM, Pritchard DJ, Burgert EO Jr, Unni KK: Ewing's sarcoma of bone. Experience with 140 patients. Cancer 58:2551-2555, 1986

106. Xu SF, Adams B, Yu XC, Xu M: Denosumab and giant cell tumour of bone- a review and future management considerations. Curr Oncol 20:e442-e447, 2013
107. Yeom JS, Lee CK, Shin HY, Lee CS, Han CS, Chang H: Langerhans' cell histiocytosis of the spine. Analysis of twenty-three cases. Spine (Phila Pa 1976) 24:1740-1749, 1999

108. Zaijun L, Xinhai Y, Zhipeng W, Wending H, Quan H, Zhenhua Z, et al: Outcome and prognosis of myelopathy and radiculopathy from osteochondroma in the mobile spine: a report on 14 patients. J Spinal Disord Tech 26:194-199, 2013

109. Zenonos G, Jamil O, Governale LS, Jernigan S, Hedequist D, Proctor MR: Surgical treatment for primary spinal aneurysmal bone cysts: experience from Children's Hospital Boston. J Neurosurg Pediatr 9:305-315, 2012

110. Zhang W, Zhang Y, Li P, Rhodesm SD, Wang Y, Xue X, et al: Administration of sodium ibandronate in the treatment of complicated giant cell tumor of the spine. Spine (Phila Pa 1976) 36:E1166-E1172, 2011

111. Zucker JM, Henry-Amar M, Sarrazin D, Blache R, Patte $\mathrm{C}$, Schweisguth O: Intensive systemic chemotherapy in localized Ewing's sarcoma in childhood. A historical trial. Cancer 52:415-423, 1983

\section{Disclosures}

Dr. Schmidt is a consultant for Ulrich Medical USA.

\section{Author Contributions}

Conception and design: Brockmeyer, Ravindra. Acquisition of data: Ravindra, Eli. Analysis and interpretation of data: all authors. Drafting the article: Ravindra, Eli. Critically revising the article: all authors. Reviewed submitted version of manuscript: all authors. Approved the final version of the manuscript on behalf of all authors: Brockmeyer. Study supervision: Brockmeyer.

\section{Correspondence}

Douglas L. Brockmeyer, Department of Neurosurgery, Clinical Neurosciences Center, University of Utah, 175 N Medical Dr. E, Salt Lake City, UT 84132. email: douglas.brockmeyer@hsc.utah. edu. 